\title{
Santiago, Guadalupe, Pilar: Spanish Shrines/Spanish Names
}

\section{STERLING A. STOUDEMIRE}

\section{$\mathrm{T}_{\mathrm{H}}$}

HE SPANIARD, FROM THE earliest days of Christianity, even before the existence of the Spanish language or the Spanish nation, has demonstrated intense fervor for the sacred images which adorn his churches, cathedrals, monasteries and other shrines. Every town, almost every parish, has its favorite image. Three of these images, two of the Holy Virgin Mary and one of a disciple, have had especial national significance, and they have crossed the frontiers of Spain to be revered in many parts of the world. These three images, in different ages and in separate regions, spanning now more than 1,000 years, have drawn to themselves the sharp focus of all of Spain. Santiago de Campostela in Galicia, Nuestra Señora de Guadalupe in Extremadura, and Nuestra Señora del Pilar in Aragon. In short, one for the north, one for the south and one for the central part of the country. The first was a powerful catalyst in forging a nation, even a religion; the second was to support Spain in her successful search for imperial and colonial power; and the third was to console Spain in her modern tragedy which has lasted more than two centuries. One for the Middle Ages, one for the Catholic Sovereigns and their successors the Hapsburgs, and one for the Bourbons. Three different locations, three different eras, but all thoroughly Spanish and national-now international.

These three shrines have been the inspiration for many names: personal names, place-names, and names of hundreds of assorted things. The history and legend of Saint James being what it is, it is not surprising to find the first has spread the place-names Santiago and San Diego around the Spanish world. Nor is it surprising to see how many personal names for boys have resulted: Santiago, Diego, Diago, Jaime, and many others. It is especially interesting that each one of these Christian names, plus other derivatives, has moved into the category of surnames to join the popular patronymics Dias and Diez. Saint James does not belong to the Spaniards, even though they may think so, but he does 
play a broader role in their world than in any other. ${ }^{1}$

There is an intimate relationship between the first shrine (Santiago, from Sanctus Jacopus) and the third (Pilar). The popularity of this third shrine dates only from the middle of the eighteenth century but its name has come to be the nombre de pila of thousands of Spanish girls, a name practically unknown until fairly recent decades, and a quite lowly name at that: "Pillar." Popular for girls in Aragon, Pilar is now circumnavigating the Spanish world. It is not surprising to see that this name, too, has moved into the category of Spanish surnames. (This only adds additional evidence to the proof that any name can become a surname.) Perhaps Queen Isabel II added certain impetus to this when in 1866 she created the title of el Conde de Pilar. An interesting example of an earlier change of a name to Pilar is that of Manuel Piquer, an eighteenth century composer of religious music at Zamora, who took the family name Pilar before entering the monastery of Nuestra Señora de Guadalupe. ${ }^{2}$ Pilar, on the other hand, has not become widely established as a place-name, especially when compared with the many places labeled Santiago, San Diego, and Guadalupe.

Saint James, in the Pilar account, shortly after the Ascension, went to Spain to carry out Christ's enjoinder to carry the gospel into all the world. ${ }^{3}$ As he was preaching up and down the banks of the Ebro River, he discovered that proselytizing the Stoic Spaniard was a task tougher than he had anticipated, for Roman Spaniards demonstrated the same zeal in adoration of their gods that they have since demonstrated for their Christian symbols. Despondent at being able to win only eight converts, James was about to abandon his mission when he was visited by the Virgin Mary. This apparition is unique in the cult of the Virgin since it was before the Assumption and the only "apparition" during her lifetime. Indeed it must have been something of a family reunion with Mary going to assist the disciple who was one of the three most closely associated with her Divine Son. Standing on a pillar borne by two angels, she urged James to lead the eight converts of his parish in building a chapel. The tradition goes on to say that such a chapel, 16 paces long and eight paces wide, was constructed in Zaragoza. This is attested by a manuscript in the cathedral, a modern document said to

1 James A. Michener, Iberia: Spanish Travels and Reflections (New York: Random House, 1969). Michener ends his book on Spain with a chapter on "Santiago de Campostela," (pp. 71594), an excellent summary of long and often conflicting ramifications of this legend. His treatment of Guadalupe (pp. 439-42) is sketchy; he does not mention Nuestra Señora del Pilar.

2 Enciclopedia universal, Espasa-Calpe, XLIV, p. 883.

3 Ibid., LIV, pp. 247-66. 
be a copy of an earlier one-a fine example of coining evidence to substantiate the beautiful and well-known legend. No trace remains of this original chapel. The present church which houses the image of the Virgin of Pilar was completed in 1753 and it was about this date that this image began to take first place among Spanish shrines. Pope Clement XII (1730-1740) changed the day of the Virgin of Pilar from January 2 to October 12 . Did Pope Clement by any chance want Pilar to be the symbol of Spanish internationalism? The day of October 12 most properly belongs to the Virgin of Guadalupe, now December 12, the day of Columbus' landfall at San Salvador, the day of the beginning of Spain in the New World for which Guadalupe is a proper symbol. It is true this change of date has been of much concern to the patriotic and faithful of Extremadura. ${ }^{4}$

The story of the shrine of Santiago de Campostela is based on the later episodes of this legend. Tradition has it that Saint James' body was discovered and returned to Spain by some of his followers, and that his grave was discovered in Galicia in 812. By the time that Latin had developed into Old French north of the Pyrenees and into Old Spanish and Old Portuguese to the south, Campostella (Campus Stellae) had come to be a shrine visited each year by thousands of pilgrims from France and other countries. Santiago de Campostela had come to be the third shrine in importance (after the Holy Land and Rome). The Way of Saint James was a well-traveled route, one branch from France crossing the Pyrenees by way of Roncesvalles, another by way of Somport, the two converging at Puente la Reina and, turning west, passing through Logroño, Burgos, León and on to the shrine of Santiago. Pope Calixto II declared the year 1122 a jubilee, and the famous cathedral was completed in 1186 , bearing the mortal remains and a fine image of the Saint. The influence of this shrine upon Christianity, and especially Spanish Catholicism, is almost immeasurable. And Saint James was honored with three days in the Spanish calendar: Patron of Spain, July 25; his apparition at the battle of Clavijo, May 23; and the Translation of his remains to the present resting place, December 23. Santiago continued to be the chief shrine in Spain, and a favorite in Christendom, down to the fourteenth century when a series of events, mainly Christian victories over the Arabs, caused Spain to turn her

4 "'Hagamos del 12 de diciembre nuestro dia, como otros pretender hacer el 12 de octubre el suyo. Demos relieve universal a la gloria de Extremadura, vinculándola a la fecha en que Guadalupe, por decisión de Roma, se hace efectivamente universal para ser celebrada por un mundo que tiene a Santa María de Guadalupe por patrona." Ricardo Becerro de Bengoa, Una voz del frente (Cáceres: Editorial Extremadura, 1973), p. 421. 
attention to the southern part of the peninsula, especially to Extremadura.

At that time many miracles were reported from Guadalupe, near Cáceres, and the monastery of Nuestra Señora de Guadalupe came to be the focus of attention of Kings, Emperors, Columbus, conquistadores, and just ordinary Spaniards. And Guadalupe came to be Spain's first shrine and held that honor down to the middle of the eighteenth century when Nuestra Señora del Pilar assumed that rank. In our present century intense rivalry has developed among the three. Since the jubilee year (a year when Saint James' day falls on Sunday) of 1965, literally millions of pilgrims have visited Santiago. The Way of Saint James once again is crowded, in a Mercedes-Benz, or a Volkswagen, or a Fiat, or a Seat, in buses, riding donkeys or mules, and a few on foot. Tourist agencies can provide any accommodation. The local authorities have constructed in Santiago economical "motel" groups to house those who can not pay the fare in expensive hotels, accommodations similar to those available in the Middle Ages. And the spacious hospital constructed by Queen Isabel for the visitor is now one of the finest hotels in Europe. At the same time, strong efforts are being made to restore Guadalupe to her former position of prestige, for she is the one that is connected with Hispanidad, Españolismo, el Día de la Raza, España en el Nuevo Mundo, etc., etc. And the same scholars in Extremadura, especially in Cáceres, who sponsor Guadalupe are those who advertise the younger Seneca (born in Córdoba) as the prototype of the ideal Spaniard. During this intense rivalry, Nuestra Señora del Pilar continues to attract her share of Spanish attention-a fine tripartite example of Spanish divisiveness, rivalry, and competition within her own borders, a hall-mark of her history.

The Guadalupe tradition begins about 600 when Pope Gregory the Great sent a handsome image of the Virgin Mary to the Archbishop of Sevilla. ${ }^{5}$ This image was established in a church somewhere in southeastern Spain. With the invasion of the Arabs in the early eighth

5 The best accounts of the history of the Monastery of Nuestra Señora de Guadalupe are by Fray Arturo Alvarez, O.F.M., who for years was archivist and librarian there: Breve guia bistórico-artistica del Real Monasterio de Guadalupe (Sevilla, 1961), and Carlos Vy el Monasterio de Guadalupe (Comillas, Santander: Universidad Pontificia, 1958). Also valuable are studies by Fray Germán Rubio, O.F.M., Historia de Nuestra Señora de Guadalupe, O sea: apuntes históricos sobre el origen, desarrollo y vicisitudes del Santuario de la Santa Casa de Guadalupe (Barcelona, 1926); Carlos Callejo, El monasterio de Guadalupe, Bol. XXI of Los monumentos cardenales de España (Madrid: Plus Ultra, [1958]); and P. Carlos G. Villacampa, O.F.M., La Virgen de la bispanidad o Santa Maria de Guadalupe en América (Sevilla: Editorial de San Antonio, 1964). 
century, Christian images were carefully hidden lest they be desecrated or destroyed by the invader. ${ }^{6}$ Once in possession of almost the entire peninsula, the Arabs began to place names on the land, as was their custom in their long migrations and conquests over the Middle East and North Africa. Many of these names remain to this day and some have been carried around the world to label other places. A small river in Extremadura was named Guadalupe (now Guadalupejo). It was normal spread for the name in time to be applied to the nearby mountains-in spite of its meaning-and then to the entire area. In the fourteenth century, or about 600 years later, many miracles were reported in Extremadura. One day a peasant was distressed to find one of his cows dead and, hoping to salvage something from this economic shock, he began to skin the animal and the cow suddenly came to life. People in the village, especially the clergy, refused to believe the story. A short time later the young son of the same peasant died and, as the child's body was being carried to the cemetery for burial, the child suddenly was filled with life. Again the local clergy were totally deaf to this report. At this point the Virgin Mary made her appearance and pointed to a spot on the ground where she wanted the people to dig. Obeying her command, the local peasants uncovered the beautiful image that Pope Gregory had sent them centuries earlier. In order to celebrate properly the appearance of the Virgin and in thanksgiving for the discovery of her image, the people constructed on that spot a fort and later a church to house the newly-found relic. This was the beginning of the cluster of buildings that in time was to grow into a large and complex monastery and destined to succeed Santiago as the chief shrine of Spain. ${ }^{7}$

In 1340 King Alfonso XI built the first important unit that was to become the famous monastery of Villuercas. In 1389 King John I presented the monastery to the Hieronymites. Over the years other kings of Castile displayed interest in Guadalupe and, with the eyes of Spain turned south, the attraction of Santiago de Campostela declined gradually almost to oblivion. The first queen of John II, María de Aragon, was interested in Guadalupe. Henry IV, brother of Queen Isabel, and his mother, repose in mummified remains on the high altar. When, nearing the end of his first voyage, Columbus ran into a violent

6 Gregorio Collado de García Aguilera, "Nuestra Señora de Guadalupe," in Becerro de Bengoa, Una voz del frente, pp. 369-73.

7 Fray Diego de Ecija, Libro de la invención de esta Santa Imagen de Guadalupe; y de la erección y fundación de este monasterio (Cáceres, 1953); and Enciclopedia Universal, EspasaCalpe, XXVI, pp. 1512-17. 
storm off Lisbon and was afraid that he would never reach Spain to report that he had reached Asia by sailing west, he called the crew together and told them to pray for the Virgin's protection, and that if they should reach haven one of their number, to be chosen by lot, would make a pilgrimage to Nuestra Señora de Guadalupe in order to return thanks to the Holy Virgin for their deliverance. Columbus placed in a hat as many chick-peas as there were members of the crew, with a cross cut into one of the garbanzos. The Admiral drew first and came up with the chick-pea with the cross. After reaching Lisbon safely, and going on to Barcelona to report to the Crown, Columbus then made the pilgrimage to Guadalupe. The monks were impressed by his sea stories and accounts of "Asia" and, if we can believe the evidence, they requested him to name something for them, some new island or land he would "discover." It was reported that Columbus made such a promise, a promise he certainly fulfilled. ${ }^{8}$

Columbus tells that when he reached the Antilles on the second voyage, November 3,1493, he named the first island Dominica "sighted on Sunday," even now bearing the same name; the next island he named Santa Maria Galante (now Marie-Galante) for his flagship; the third, Todos los Santos (now Les Saintes), for All Saints' Day just past. Then he came to the big kidney-shaped island which he named Santa Maria de Guadalupe (now the French Guadeloupe) thus fulfilling his promise to the Hieronymites in Spain. ${ }^{9}$ This was the first transfer of

8 "Jueves 14 de Hebrero [1493] : Esta noche creció el viento y las olas eran espantables, contrarias una de otra, que cruzaban y embarazaban el navío, que no podía pasar adelante ni salir de entremedias dellas y quebraban en él. Crecía mucho la mar y el viento y, viendo el peligro grande, comenzó a correr a popa a donde el viento lo llevase. . . El ordenó que se echase un romero que fuese a Santa María de Guadalupe y llevase un cirio de cinco libras de cera, que hiciesen voto que al que cayese la suerte cumpliese la romería, para lo cual mandó traer tantos garbanzos cuantas personas en el navío venían, y señalar uno con un cuchillo haciendo una cruz y meterlos en un bonete bien revueltos. El primero que metió la mano era el almirante y sacó el garbanzo de la cruz, y así cayo sobre él la suerte." Diario del primer viaje de Colón, texto revisado por Antonio Vilanova, prólogo de Gregorio Marañón (Barcelona: Ediciones Nauta, S.A., 1965), pp. 131-32.

9 Hernando Colón, Vida del Almirante Don Cristóbal Colón, escrita por su hijo ... Edición, prólogo y notas de Ramón Iglesia (México: Fondo de Cultura, 1947, p. 144; and Samuel Eliot Morison, Christopher Columbus, Mariner (New York: Mentor Books, [1956]), p. 75. Columbus seemed to think that a part of his divinely directed mission was to bestow names on almost everything. He began this regrettable practice with his first landfall at San Salvador and continued it on all four voyages, giving labels to at least 100 islands, capes, bays, rivers, valleys, mountains, etc. He expressed in the names his gratitude to God, Christ, the Virgin Mary, the Church, the Royal family, his friends, his ships. An occasional name was descriptive or the suggestion of the immediate moment. Some of these names still exist: San Salvador, Trinidad, Guadalupe (Guadeloupe), Montserrat, Tortuga, Dominica, San Jorge, Santo Domingo, Gracias a Dios, et al. Some have been renamed: Fernandina (Long Island), Isabela (Crooked Island), 
this Hispano-Arabic name outside of Spain. At the end of the second voyage Columbus did not get to Guadalupe until 1496 . We can assume that with pleasure he told the monks he had given their name to a new island. The monastery records show that in that year two American Indians were baptized there and given popular Spanish names: Pedro and Cristóbal. ${ }^{10}$ One immediately assumes that the baptism and Columbus' visit must have coincided.

During these years Ferdinand and Isabel visited Guadalupe at least eight times. Ferdinand died there January 23, 1516. The Emperor Charles V visited Guadalupe first in 1525, and many times later; abdicating as King of Spain (1556) and retiring to nearby Yuste, February 3 , 1557, he visited the monastery once a month until his death the following year. Hernández de Córdoba (El Gran Capitán), in the company of the Catholic Sovereigns, was there in June, 1492. Ferdinand Columbus, the Duke of Alva, other nobles, and Cervantes visited the shrine and its popularity continued to grow. ${ }^{11}$ The Santa Catalina chapel there was selected as the burial place of Prince Dionis of Portugal and his wife. Both Andrea Doria and Don Juan de Austria visited there. Hernán Cortés was born in Medellín, only a few miles away, in 1485 , and it is well known that he and his men carried a knowledge and love of Guadalupe to Mexico where we find another chapter in the legend, the story of Juan Diego and the hill of Tepeyac. Juan Diegonote the Christian name-had several encounters with the Virgin Mary on the hill of Tepeyac. This only apparition of the Virgin in the New World had profound influence on the indio and Spaniard alike. Later it would exert the same influence on the third ethnic element, the Mexican. The Virgin spoke to Juan Diego in his native tongue, and it was on his tilma that she left her portrait. This meant to the Aztecs that she was one of them. Juan Diego carried the tilma to Bishop Zumárraga, a most proper sort of message since these Indians had no alphabet, only a type of picture writing with which they recorded their history. Cortés

Concepción (Rum Cay), Guadalquivir (Les Trois Rivières), Rio del Oro (Río Yaque del Norte), San Martin (Nevis), et al. Others have been translated into English or French: Once Mil Virgenes (Virgin Islands), Todos los Santos (Iles des Saintes), Santa Cruz (Saint Croix); and a few have regained their Caribe names: Juana (Cuba), Santiago (Jamaica), Puerto Grande (Guantánamo), Asunción (Tobago), et al.

10 Revista del Monasterio de Nuestra Señora de Guadalupe, nov.-dic., 1968, num. 578.

11 The pilgrims in Cervantes' Persiles visited Guadalupe and their reaction must reflect that of Cervantes. "Quatro dias se estuvieron los peregrinos en Guadalupe, en los quales començaron a ver las grandezas de aquel santo monasterio; digo començaron, porque de acabarlas de ver es imposible." Miguel de Cervantes Saavedra, Persiles y Sigismunda, ed. Rodolfo Schevill y Adolfo Bonilla, 2 vols. (Madrid: Imprenta de Bernardo Rodríguez, 1914), II, 58. 
had been recalled to Spain in 1528 , a little more than two years before this appearance of the Virgin. He went to Guadalupe where he spent a novena in prayer and, cleared of all charges against him, he returned to Mexico, arriving at Vera Cruz, July $15,1530 .{ }^{12}$ The Virgin's first appearance was Saturday, December 9, 1531, and later three other times, all to Juan Diego. She asked that a church be built on the spot of their meeting. The messages were relayed to the bishop but he and his staff paid small attention until Juan Diego came a fourth time with his rebozo filled with roses, so he thought, that had appeared miraculously on the hill of Tepeyac. Then the bishop and his retinue at last took decisive action, for Juan Diego reported that the church should be constructed and that it should be named Nuestra Señora de Guadalupe, and that his tilma's Virgin should bear the same name. The basilica was built, and named Guadalupe. Columbus had established the first name of Guadalupe on an island of the Lesser Antilles in 1493, a little more than a year after his landfall at San Salvador. Thirty-nine years after the "discovery" Our Lady appeared at Tepeyac, and the Hispano-Arabic name was transferred to American soil for the second time. Since then the name has literally circled the globe.

The legendary details of finding the image of the Virgin at Guadalupe in Spain and at Tepeyac in Mexico are striking in their similarity. Both images were dark of complexion, morenitas, one for the dark-skinned descendants of the Moriscos of southern Spain and the other for the bronze-skinned indio of Mexico.

In southern Spain the monastery of Nuestra Señora de Guadalupe had fallen on evil days, declining gradually until the Hieronymites were expelled in 1835, after living and working in the sacred spot for more than 400 years. Pillage and vandalism removed or destroyed many of the fine furnishings of the monastery. It is something of a miracle that many of the priceless objects remained, especially the paintings of Zurbarán-of monks of the seventeenth century. In 1879 a program was begun to attempt to restore the shrine to its earlier splendor and in 1908 Spain's favorites, the Franciscans, moved in and initiated a methodical program aimed at full restoration, often buying back art objects that had disappeared years before. They went about the orderly process of making Nuestra Señora de Guadalupe the center of Hispanidad, Españolismo, and Internacionalismo. Dr. Ricardo Becerro de

12 Salvador de Madariaga, Hernán Cortés: Conqueror of Mexico, 2nd edition (Chicago: Henry Regnery Company, 1955), pp. 452-53; and Bradley Smith, Mexico: a History in Art (Mexico, D.F.: Editora Cultural y Educativa, 1968), pp. 184-86. 
Bengoa of Cáceres has been the leading spirit among the laymen in this crusade.

From the transfer of the name Guadalupe to the island in the Caribbean and then to Mexico, the designator has literally exploded around the world as a place-name. It is the name itself, its symbolism and not its basic meaning, that has made it one of the most common placenames in the Spanish world. Its sonorous beauty has certainly added to its popularity. At least three etymologies have been suggested for this name. The first and most popular is a combination of the Arabic word [Wadi-] "river" and [Lupe] from the Latin lupus, "wolf,": "River of the place of wolves." One thing there is suspect: the Arabs, coming from areas blessed with few streams, in their joy at finding water, were in the habit of naming rivers completely, not by combining their word for river with a Roman descriptive term. (There are 50 and more streams, large to small, in Spain with the first syllable the Arabic Guada or Guadi: Guadalquivir, Guadalete, Guadiana, Guadarrama, Guadalupejo, Guadaira, Guadalaviar, Guadalcotón, and many more.) The second etymology is [Wadi-] plus the Arabic [Ugaibi], "hidden, secret": "Secret River or Underground River." The third is the soundest: [Wadi-al-lub], "Río de cascajo negro," a river with disintegrating black stones and pebbles in its bed. In addition to being sound linguistically, this etymon follows the Arabic pattern all over the world of the Middle Ages, and especially in Spain. Gutierre Tibón, the distinguished Mexican onomatologist, after long investigation, has come to this conclusion, and one of my colleagues, the Arabist Dr. Julio Cortés, assures me that this is correct. ${ }^{13}$ The present writer can testify that the river bed of Guadalupejo (Guadalupe) is black. But there always comes a time when a name loses its meaning and remains only a label. In this case the meaning of Guadalupe and the dissemination of the word are wholly unrelated. It is to be doubted that either Columbus or Cortés had the slightest idea as to its meaning. Perhaps they knew that Guad meant river. It would be a rare Spaniard that could not make that simple deduction.

In summary: There are many other Christian shrines in the Iberian Peninsula that are highly revered by the faithful, and some not so faithful, notably Nostra Senyora de Montserrat of the Catalans and Nossa Senhora do Rosário da Fátima of the Portuguese. But the three discussed here are the lodestars of the Spaniards. One temple in Galicia,

13 Gutierre Tibón, Onomástica hispanoamericana . . . México: Unión Tipográfica Editorial Hispano Americana, 1961, p. 137. 
one in Extremadura, and one in Aragon, each regional at first, then national, with two strongly international with the third rapidly moving into that category.

Pilar $^{14}$ (pillar), the latest to join the list, has come to be the name of many girls of Aragon, and now this nombre de pila has spread to all Spain and to a large part of the Spanish world. The spirit behind this common noun gives it dignity and covers it with reverence. Pilar and Pilares have crossed into the list of surnames. And it is not surprising to find that both of these designations are place-names and to be found, but not in large numbers, around the world. It is also attached to many "things." A good, a very Spanish example, is Ernest Hemingway's Cuban boat Pilar.

Few names, anywhere or in any language, have spawned so many offspring (nombres de pila, apellidos, patronimicos, lugares, cosas) as has Santiago (Sanctus Jacopus). The given names are numerous: Diago, Diego, Diegues, Diéguez, Jácobe, Jácobo, Jácome, Jaime, Jaimes, Jaimez, Jaume, Santiago, Tiago, Yago, Yagües, and there must be others, and each one of these has become a surname, along with the popular patronymics Díaz and Díez. Nor is it surprising to find the world-wide Santiago and San Diego joined by Diago, Diego, Jaime, Diaz and Diez as place-names, and there must be others here, too. In the category of "things," one of Columbus' ships of the fourth voyage and one of Magellan's bore the proud name Santiago. Both were wrecked. Santiago Diago's parents showed great faith in the saint when they chose the nombre de pila for their son.

The Arabic Guadalupe "Black River" is the most intriguing of the names of these three Spanish shrines. First a clearly descriptive term, placed by the invading Moslem on a river then, with the original meaning practically forgotten, it began to spread in southern Spain, and finally coming to be the label of the most revered spot in the peninsula, after the decline of Santiago, then moving to the Antilles with Columbus and within a few years on to Mexico. In this migration Guadalupe became something of a mark of Spanish internationalism. From a place-name it moved rapidly to the category of given names for girls and Guadalupe in Mexico becomes what Pilar is in Aragon and Diego and Jaime are all over the Spanish world. The form and beauty of the word suggest its conversion into pet names: Guadalupita, Gualupita, Lupe, Lupita, Pita. (As one Mexican put it "Many girls are named

14 A number of dictionaries, encyclopedias, other reference works, as well as telephone directories of the larger Spanish and Spanish American cities, have been consulted in preparing this paper. 
Guadalupe, many boys Cuaubtémoc, but not one Hernán.') Guadalupe, Guadalupo, and Pita are now surnames. And we should be remiss if we did not point out that Guadalupe with all its derivatives is attached to those things usually bearing feminine names: yachts, boats, ferryboats, taxicabs, mountain lodges, and pets of many genera.

In spite of its length, Guadalupe, in good old Spanish custom, is often combined with another descriptive native Mexican term, producing a label in size dear to those south of the border. "Pero es en México donde el nombre adquiere una nueva carta de ciudadanía, y donde a menudo se copla con topónimos autóctonos, formando binomios [Guadalupe Pantzingo and Guadalupe Analco (Puebla), Guadalupe Etla (Oaxaca), Guadalupe Atla (Aguascalientes), Guadalupe Ixcotla (Tlascala), Guadalupe Yancuitlapan (México) and many others] del sabor más simpáticamente mestizo."15 Yet it is as a place-name that Guadalupe has circled the globe. Several hundred names of rivers, islands, mountains, valleys, towns, counties, etc., in many countries, have been collected and the list continues to grow. "Guadalupe es nombre de sierra, nombre de rio, nombre de Virgen, nombre de monasterio, y asimismo nombre de parroquia [y nombre de pila y de familia]. Yuste, Guadalupe. Fuimos en Yuste los últimos de Europa; en Guadalupe los primeros en América. La tumba del Sacro Romano Imperio Germánico la abre Yuste; erige Guadalupe la pila bautismal de un Nuevo Mundo ... Extremadura se lanza al infinito."16

University of North Carolina

Chapel Hill

15 Tibón, op. cit., p. 136.

16 Pedro de Lorenzo, "Cáceres," in La España de cada provincia (Madrid: Publicaciones Españolas, 1964), pp. 154-55. 